\title{
Light fluctuations, crown traits, and response delays for tree saplings in a Costa Rican lowland rain forest
}

\author{
FRANK J. STERCK*, DAVID B. CLARK $\dagger$, DEBORAH A. CLARK $\dagger$ and \\ FRANS BONGERS*
}

* Sub-Department of Forestry, Department of Environmental Sciences, P.O. Box 342, Wageningen Agricultural University, 6700 AH Wageningen, The Netherlands

† La Selva Biological Station, Organization for Tropical Studies, Apartado 676, San Pedro 3050, Costa Rica

(Accepted 29 July 1998)

\begin{abstract}
Light fluctuations and crown traits were studied for saplings of four tree species in a Costa Rican rain forest. Light fluctuations (1988-1994) were assessed by annual light estimations above saplings, using a visual crown position index. Crown traits in 1994 and growth between 1994 and 1995 were measured. Crown position values varied between 1.5 and 2.5. Of the 70 saplings only four were found at higher light levels (crown position of 3 or 3.5), but for $1-2 \mathrm{y}$ only. Over the 6 y of investigation, 55-75\% of the saplings experienced no or only one light fluctuation, and 25-45 \% two or three fluctuations. Crown traits in 1994 were either most strongly correlated with light levels in 1993 (Lecythis) and with light levels in 1991 and 1992 (Dipteryx and Simarouba), or they were not significantly correlated with light levels (Minquartia). It is hypothesised that: (1) the saplings require $1-3$ y to establish a crown trait in response to light levels in the forest; and (2) and species that can economically produce a leaf can adjust crown traits more quickly in an environment dominated by low light levels than species that are less economic. Crown trait responses may track environmental changes in three of the four species, in particular in Lecythis. In this latter species, leaf area had no significant effect on growth and survival, whereas light level had a positive effect. Conversely, in the other three species, light levels had no discernible effect on growth and survival (due in part to low variation in crown position in two of these species), whereas leaf area had a positive effect on both.
\end{abstract}

KEY WORDS: architecture, Costa Rica, crowns, environmental fluctuations, growth response, light environment, rain forest, saplings, tree morphology, tree performance

\section{INTRODUCTION}

Light environments in tropical rain forests vary in both space and time (Chazdon \& Fetcher 1984). Low light levels dominate in the forest understorey. 
They abruptly change into higher light levels when a tree or branch falls and light penetrates directly through the canopy gap formed. Canopy gaps close and light availability returns to the common low level within 5-10 y (Van der Meer 1997). Gap opening and filling processes thus create fluctuations in light which might influence the growth of tree saplings in the forest understorey.

Saplings respond to the light fluctuations by changing growth, architecture, and physiology. These responses have been demonstrated experimentally for trees grown at constantly high and low light levels (Augspurger 1984, Popma \& Bongers 1988), or for trees switched from one light level to another (Fetcher et al. 1987, Osunkoya \& Ash 1991). Seedlings changed their morphology within weeks (Ackerly 1997) or months (Popma \& Bongers 1991) after a switch, depending on the type of response and the species. Because these experiments used controlled light environments, they do not demonstrate how plants respond to light fluctuations in the natural forest situation.

In forests light levels vary on different time scales. Each of these scales initiates its own plant responses (Chazdon 1988, Gross 1986). We considered light fluctuations on a scale of years and the responses in crown traits (crown size and leaf display) to these fluctuations. The ecological consequences of crown trait responses were evaluated from two perspectives: (1) Depending on the rate of response relative to the rate of light change, a plant trait either establishes in the light environment it is adjusted to, or it integrates responses to various light environments of the past (Ackerly 1997, Levins 1968). (2) Crown traits, such as leaf area, determine the carbon gain of the whole plant, in interaction with the light levels received by that leaf area and the efficiency with which light is converted to assimilates (photosynthetic parameters). Thus, crown traits, response rates of crown traits, and rates of light fluctuations might influence future growth and survival of saplings in the understorey. So far, these factors have hardly been assessed for natural sapling populations (but see Clark et al. 1996, Oberbauer et al. 1993, Rich et al. 1993).

In the present study, we compared saplings of four neotropical rain forest tree species, reporting the light fluctuations to which they were exposed, crown traits, relationships between crown traits and current and past light levels, and the consequences of crown traits and light on sapling growth and survival. The focus was on 1-m-tall saplings in their natural light habitats. The following questions were addressed: (1) To what light levels and fluctuations were saplings exposed? (2) What crown traits did saplings have? (3) How did crown traits vary in relation to light levels in the past and the present? (4) How long did it take crown traits to become established? (5) Did crown traits and light levels contribute to sapling growth and/or survival?

\section{METHODS}

Study site and species

The study was carried out in primary rain forest at the La Selva Biological Station in the Atlantic lowland of Costa Rica ( $\left.10^{\circ} 26^{\prime} \mathrm{N}, 84^{\circ} 00^{\prime} \mathrm{W}\right)$. The forest 
has been classified as tropical wet forest in the Holdridge Life Zone System (Hartshorn 1983). Rainfall averages $c .3900 \mathrm{~mm} \mathrm{y}^{-1}$, with no month averaging $<100 \mathrm{~mm}$; temperature averages $25.8^{\circ} \mathrm{C}$. (Sanford et al. 1994).

Saplings of $c .1 \mathrm{~m}$ high were randomly selected from an inventory of $c .150$ ha of forest (Clark \& Clark 1992), in which individuals were recorded irrespective of their vigour, form or micro-habitat.

The species selected for the present study were: Dipteryx panamensis (Pittier) Record and Mell (Papilionaceae), Lecythis ampla Miers (Lecythidaceae), Minquartia guianensis Aubl. (Olacaceae) and Simarouba amara Aubl. (Simaroubaceae). Henceforth, the species will be referred to by their generic names only. Dipteryx and Lecythis are emergent species, and Minquartia and Simarouba are canopylevel species (Clark et al. 1993).

\section{Field measurements}

The light environments of individuals were based on a modification of Dawkins \& Field's (1978) crown position index, for which increasing index values correspond with increasing levels in light availability (Clark et al. 1993). The index is based on the vegetation structure around and above the focal tree: 1, no direct light; 2, crown lit only from the side; 3, partial (10-90 \%) vertical illumination; 4 , full vertical illumination; and 5 , crown fully exposed to vertical and lateral light. The category 'crown lit only from the side' was subdivided into high (2.5, exposed to at least one major opening or multiple medium-sized ones), low (1.5, no large or medium openings), and intermediate categories (2, Clark \& Clark 1987, 1992). For each sapling, the index was assessed annually by two independent observers. Annual estimates of light environments were calculated as the average of two independent observations.

A set of crown traits was measured and calculated for each sapling in March 1994. The widest crown width was measured, as was the crown width perpendicular to it. The leaves were counted for Lecythis and Minquartia, and the leaflets for Dipteryx and Simarouba. Leaf and leaflet size (area per leaf or leaflet) were determined from a sample $(\mathrm{n}=30)$, and regressed upon leaf or leaflet) length and width $\left(\mathrm{r}^{2}\right.$ between $\left.0.90-0.93\right)$. From these data, we calculated sapling leaf area (number of leaves $\times$ mean leaf size), crown cover $\left(\frac{1}{4} \times\right.$ crown width $_{1} \times$ crown $^{2}$ width $\left._{2} \times \pi\right)$ and leaf area index (leaf area/crown cover).

Growth and survival were determined for each sapling (1994-1995). Height gain $(\mathrm{cm})$ was determined from height measurements in March 1994 and 1995, with a folding ruler. Diameter growth $\left(\mathrm{mm} \mathrm{y}^{-1}\right)$ was measured with callipers over the same period, at a permanently-marked position $40 \mathrm{~cm}$ from the base of the stem.

\section{Statistical analyses}

Crown traits were compared among species, using the Kruskall-Wallis and Mann-Whitney U-tests. Light levels in successive years (1988-1994) were correlated to each other and to the crown traits in 1994 using Spearman's rank 
correlation test. The influence of leaf area and light environment on height growth and on diameter growth was determined. The calculation of the influence of leaf area is complicated by the linear relationship between leaf area on the one hand, and height and diameter on the other hand. We calculated the residuals of leaf area regressed upon height in order to obtain a measure of leaf area (the residual) irrespective of sapling size. Consequently these residuals were used as measures of leaf area, and they were regressed upon height growth and diameter growth, respectively. The light environment was calculated as the average of the crown positions in 1994 and 1995. Crown position was 1.5 for 54 individuals, and between 1.75 and 2.5 for the other sixteen. We excluded Minquartia and Simarouba from the calculation of the light effect because only one-two individuals were exposed to crown positions $>1.5$. Of the other two species eight (Dipteryx) and five (Lecythis) individuals had crown positions $>1.5$. Because there were only a few observations for individual crown position categories $>1.5$, we included light levels in the regression model as a dummy variable that was set at 0 when the crown position was 1.5 in both years, and set at 1 when the crown position was $>1.5$ in either year. The influence of leaf area and light environment on survival was not tested statistically, since only a few individuals died between 1994-1995.

\section{RESULTS}

\section{Light fluctuations}

The crown position values tended to decrease over time (Figure 1). Few individuals of any species had a crown position of 1.5 before 1990. From 1991 onwards, most individuals had a crown position of 1.5. This trend was strongest for Minquartia and Simarouba. A crown position >1.5 was found only for two individuals of these two species in 1993 and 1994, and in five and seven individuals respectively of Dipteryx and Lecythis.

Crown position values varied between 1.5 and 2.5, except for four individuals that had a higher crown position for 1-2 y (Figure 1). Most individuals experienced light fluctuations between 1988-1994. If light change was expressed as a change from one crown position value to another (Figure 2), $>80 \%$ of the individuals per species were exposed to light changes over the $6 \mathrm{y}$ studied. Between 55-75\% experienced one light change maximally and 25 to $45 \%$ at least two light changes. These patterns were similar for the four species studied. Four individuals experienced light changes greater than 2 on the crown position scale in successive years. Two of these individuals were exposed to two such major light changes, and in both cases an increase was followed by a decrease (Figure 1). This suggests that the new canopy openings above 1-m-tall saplings closed within just $1-2 \mathrm{y}$.

Crown positions in 1994 were correlated with crown positions measured in preceding years (Figure 3). Correlations gradually decreased in strength from 

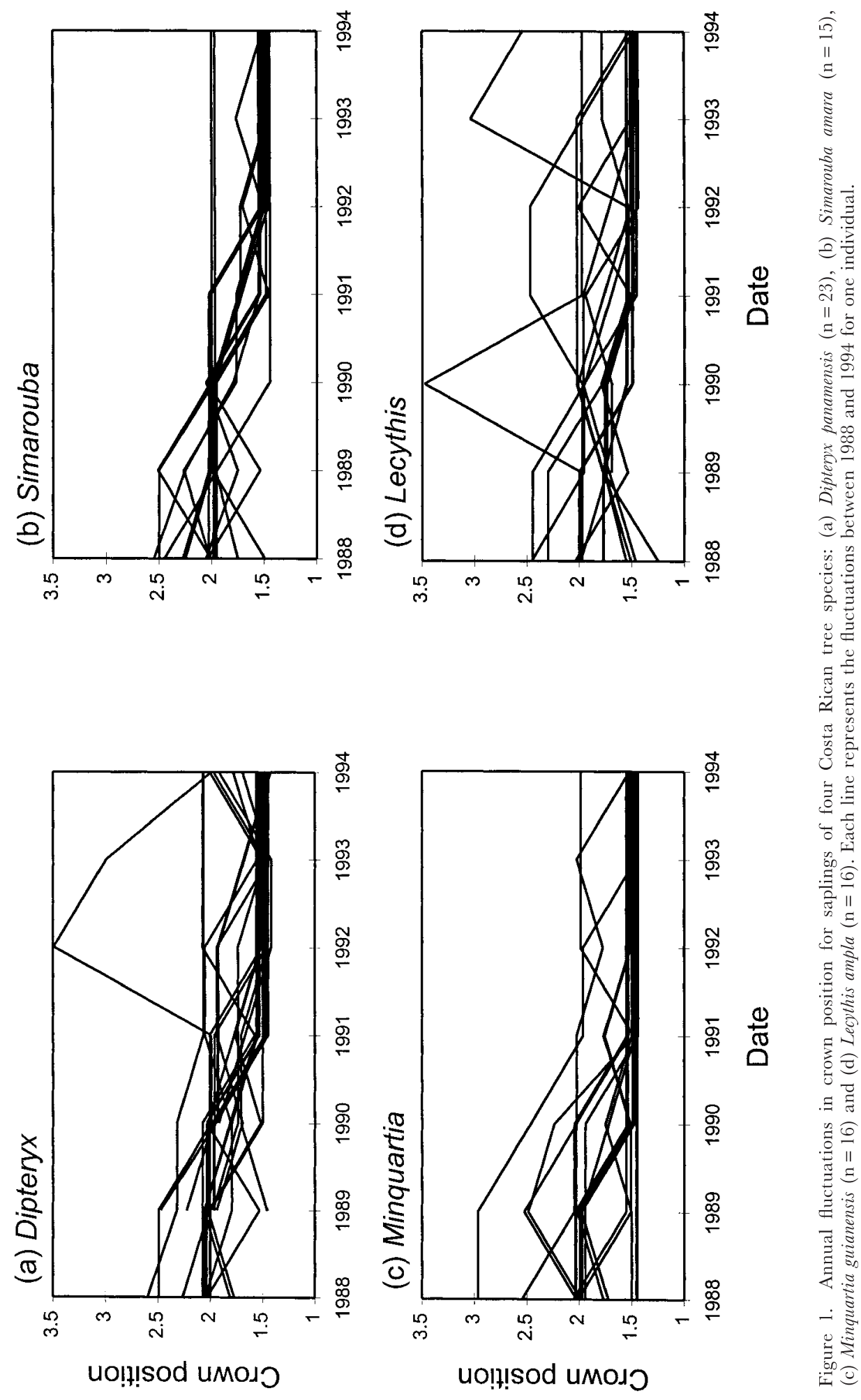


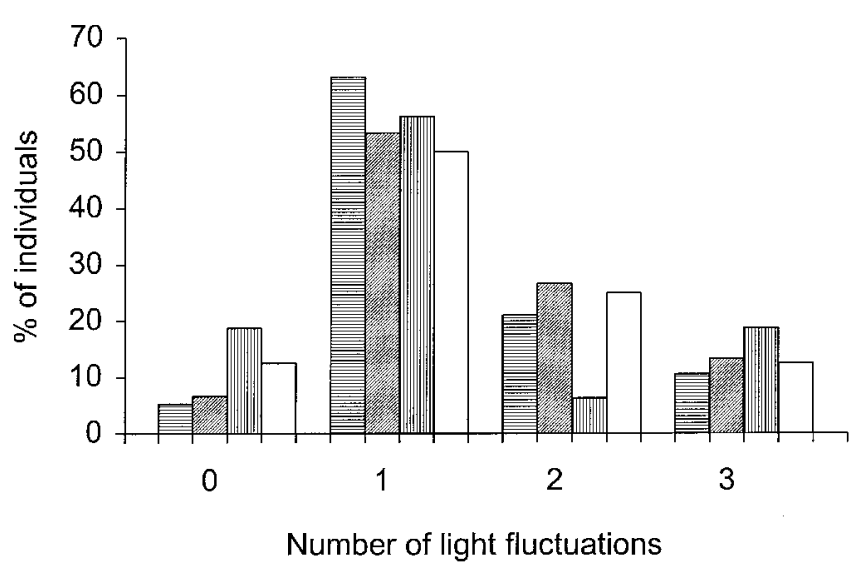

Figure 2. Frequency diagrams for the number of light fluctuations experienced by saplings of four Costa Rican tree species between 1988 and 1994. Sample sizes are given in Figure 1. 目 Dipteryx panamensis, 细 Simarouba amara, $\mathbb{U}$ Minquartia guianensis, $\square$ Lecythis ampla.

1994 to 1988, and were only significant for 1994-1993 in Lecythis and for 19941992 in the other species.

\section{Crown traits}

There was a strong contrast in the crown traits of the four species (Table 1). Crown traits were related to the architectural types of the species (Kohyama 1987, Kohyama \& Hotta 1990). Dipteryx and Simarouba saplings belong to an architectural type with a vertical trunk, no branches, and large compound leaves (they start to branch when $c .2-5 \mathrm{~m}$ tall). These species had few leaves and had the smallest crown width and leaf area. Minquartia belongs to a type with a vertical trunk and horizontal branches with large simple leaves.

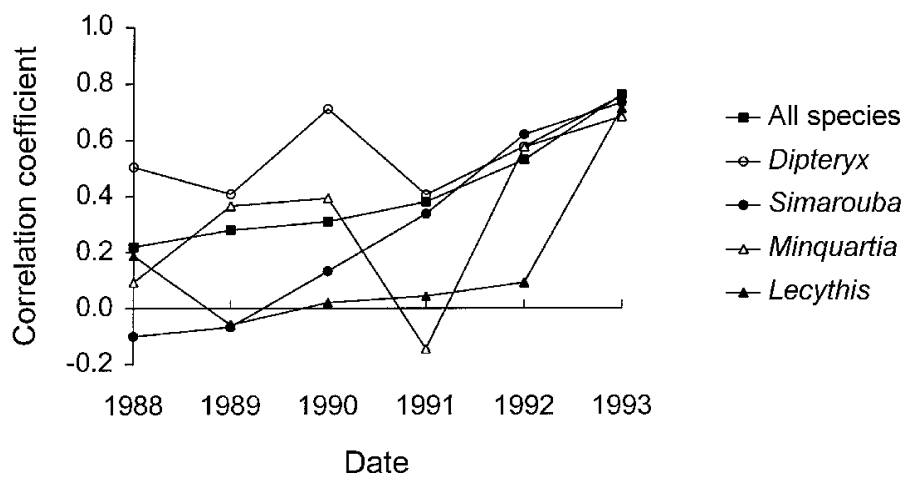

Figure 3. Spearman's correlation coefficients between the crown positions in 1994 and the crown positions in the preceding years, based on crown position estimations for saplings of four Costa Rican tree species. Sample sizes are given in Figure 1. Significance coefficients $(\mathrm{at} u=0.05)$ levels (two-tailed) are at $\mathrm{r}_{\mathrm{s}}=0.22$ (all species), 0.42 (Dipteryx panamensis), 0.52 (Simarouba amara), 0.50 (Minquartia guianensis), and 0.50 (Lecythis ampla). 
Table 1. Light environment and plant traits for saplings of four rain forest tree species at La Selva, Costa Rica.

\begin{tabular}{|c|c|c|c|c|c|}
\hline $\mathrm{n}$ & $\begin{array}{c}\text { Dipteryx } \\
\text { panamensis } \\
23\end{array}$ & $\begin{array}{c}\text { Simarouba } \\
\text { amara } \\
15\end{array}$ & $\begin{array}{c}\text { Minquartia } \\
\text { guianensis } \\
16\end{array}$ & $\begin{array}{c}\text { Lecythis } \\
\text { ampla } \\
16\end{array}$ & $\begin{array}{l}\mathrm{P}^{1} \\
<\end{array}$ \\
\hline \multicolumn{6}{|l|}{ Crown position } \\
\hline Median & 1.5 & 1.5 & 1.5 & 1.5 & \\
\hline Range & $1.5-3.5$ & $1.5-2.5$ & $1.5-3.0$ & $1.5-3.0$ & \\
\hline \multicolumn{6}{|l|}{ Architecture } \\
\hline Crown cover $\left(\mathrm{m}^{2}\right)$ & $0.17 \mathrm{a}$ & $0.26 \mathrm{~b}$ & $0.59 \mathrm{bc}$ & $0.75 \mathrm{c}$ & 0.001 \\
\hline Leaf area $\left(\mathrm{m}^{2}\right)$ & $0.13 \mathrm{a}$ & $0.11 \mathrm{a}$ & $0.46 \mathrm{a}$ & $0.21 \mathrm{a}$ & 0.017 \\
\hline Leaf area index & $0.95 \mathrm{c}$ & $0.54 \mathrm{~b}$ & $0.75 \mathrm{bc}$ & $0.28 \mathrm{a}$ & 0.001 \\
\hline No of leaves & $3.0 \mathrm{a}$ & $9.3 \mathrm{~b}$ & $46.3 \mathrm{c}$ & $248.0 \mathrm{~d}$ & 0.001 \\
\hline Leaf size $\left(\mathrm{cm}^{2}\right)$ & $449.8 \mathrm{c}$ & $124.0 \mathrm{~b}$ & $90.4 \mathrm{~b}$ & $8.1 \mathrm{a}$ & 0.001 \\
\hline \multicolumn{6}{|l|}{ Growth } \\
\hline Height $\left(\mathrm{cm} \mathrm{y}^{-1}\right)$ & $5.7 \mathrm{a}$ & $6.8 \mathrm{a}$ & $8.9 \mathrm{a}$ & $7.73 \mathrm{a}$ & 0.800 \\
\hline Diameter $\left(\mathrm{mm} \mathrm{y}^{-1}\right)$ & $0.25 \mathrm{a}$ & $0.24 \mathrm{a}$ & $0.46 \mathrm{a}$ & $0.35 \mathrm{a}$ & 0.472 \\
\hline
\end{tabular}

${ }^{1}$ P-value of Kruskal-Wallis test for interspecific differences; significant differences among species are indicated by different letters (Mann-Whitney U-test).

Lecythis conforms to the type with mixed axes (vertical at base, horizontal near apex) with small simple leaves. Its branches are hardly or not distinguishable from its trunk within the crown. The two branched species had more leaves and had the widest crowns and largest leaf areas. The species also differed in leaf area index, which was lowest in Lecythis.

Most of the crown traits in 1994 were positively correlated with crown position between 1990 and 1994, except for the leaf area index that either correlated negatively (Dipteryx and Simarouba) or did not correlate at all with crown position (Figure 4). Correlations were significant in 11 cases for Dipteryx, six cases for both Lecythis and Simarouba, and one case for Minquartia. The correlations increased from non-significant levels in 1988 to significant ones in 1991 and 1992 (Simarouba, two variables; Dipteryx, three to four variables) or 1993 (Lecythis, four variables), and then decreased to non-significant levels in 1994. There was no such pattern in Minquartia.

\section{Growth and survival}

Leaf area (corrected for size effects) positively affected height growth and/ or diameter growth in all species except Lecythis (Table 2). In contrast, crown position positively affected the diameter growth in this last species. Crown position did not significantly affect growth in Dipteryx (but $\mathrm{P}=0.08$ in case of diameter growth), while this could not be analysed for Minquartia and Simarouba because the variation in light was too small.

The influence of leaf area and crown position on survival was not tested statistically. Yet, the saplings with the smallest leaf areas died in 1994-1995 in case of Dipteryx, Simarouba and Minquartia. All Lecythis saplings survived. 

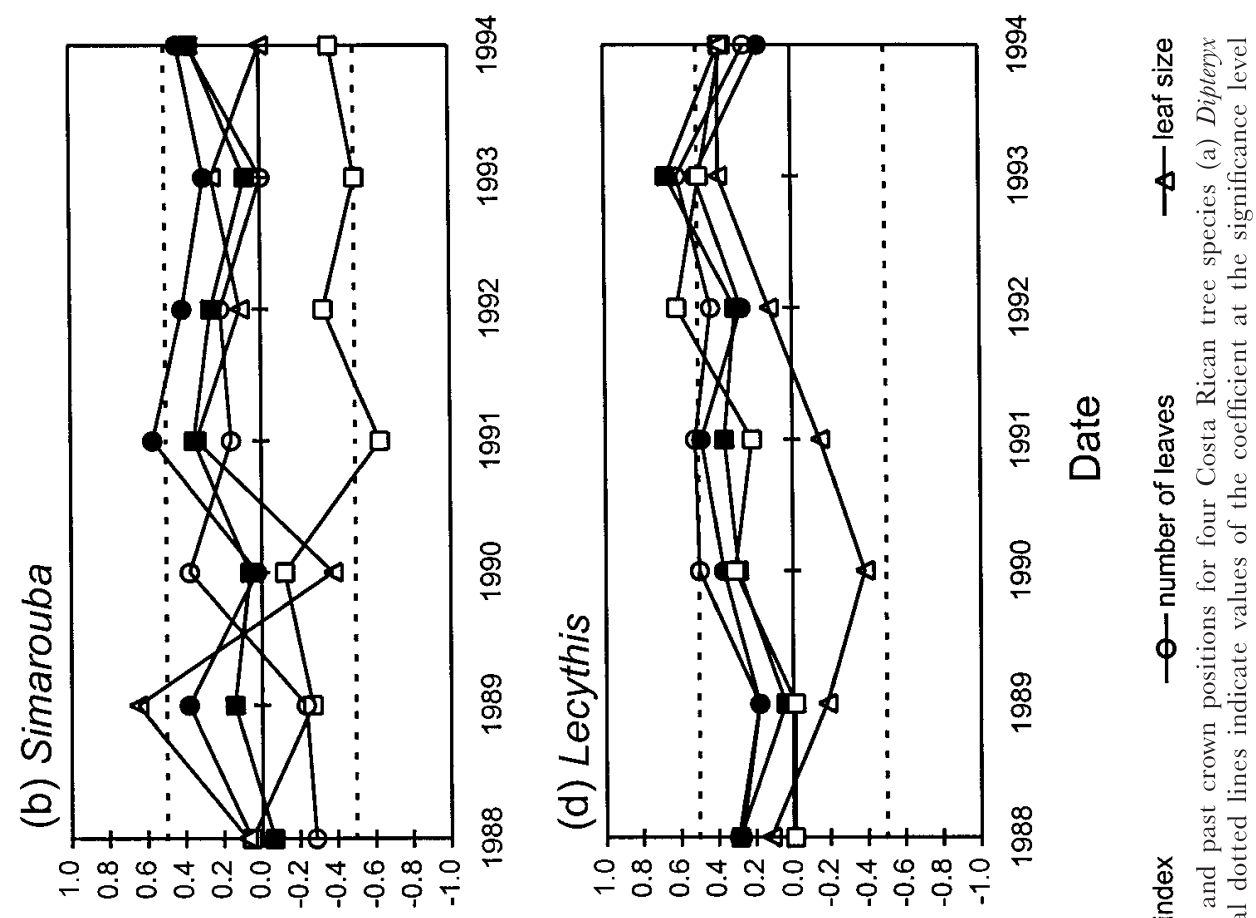

$\exists \pm$
$\Xi \vec{\sigma}$

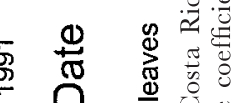

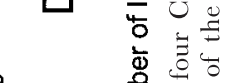

E

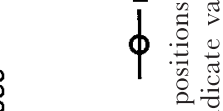

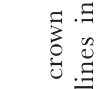

×ั

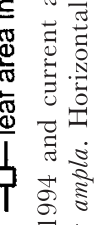

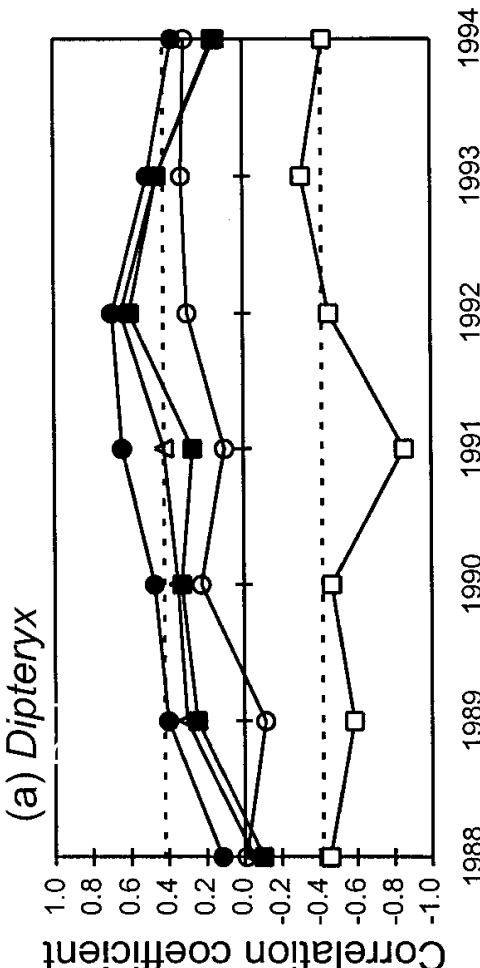

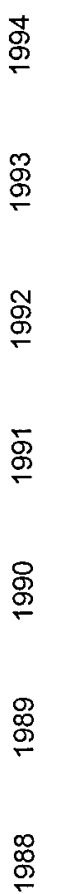

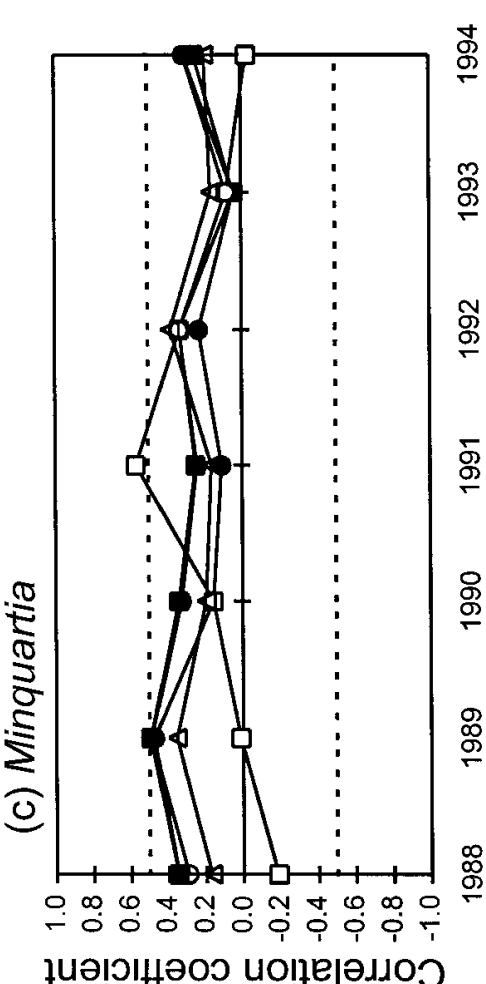

孛

兽

है

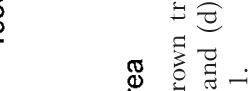

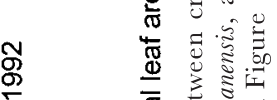

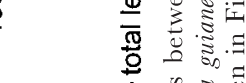

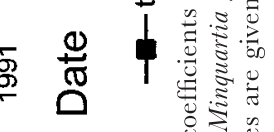

$8 \quad$ 可.

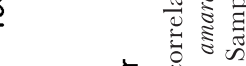

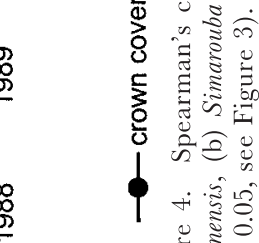

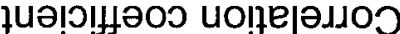


Table 2. Multiple regressions of height growth $\left(\mathrm{cm} \mathrm{y}^{-1}\right)$ and stem diameter growth $\left(\mathrm{mm} \mathrm{y}^{-1}\right)$ on leaf area (T) and light (L) for four rain forest tree species in Costa Rica. The following model was used: growth= $c+b_{1} T+b_{2} L$. The leaf area $T$ is expressed as the residual from the linear leaf area - sapling height regression $\left(\mathrm{m}^{2}\right.$, see text), and light $\mathrm{L}$ as the dummy value of the crown position ( 0 when $1.5,1$ when $>1.5$, see text). In addition, $c$ is the constant, and b's are the regression coefficients. The $\mathrm{b}_{2} \mathrm{~L}$ product was excluded from the equation for Simarouba and Minquartia, since saplings of these two species hardly differed in crown position (in 1994/1995).

\begin{tabular}{|c|c|c|c|c|}
\hline Species & $r^{2}$ & $\mathrm{c}$ & $b_{1}$ & $\mathrm{~b}_{2}$ \\
\hline Height growth & & & $\left(.10^{-2}\right)$ & \\
\hline Dipteryx panamensis & $0.25 *$ & 4.6 & $1.2 *$ & -0.6 \\
\hline Simarouba amara & 0.00 & 8.4 & -0.0 & \\
\hline Minquartia guianensis & $0.44 * *$ & $6.2 * * *$ & $0.2^{* *}$ & \\
\hline Lecythis ampla & 0.06 & 3.9 & 0.1 & 7.7 \\
\hline Diameter growth & & & $\left(.10^{-4}\right)$ & \\
\hline Dipteryx panamensis & $0.42 *$ & 0.13 & $7.2^{*}$ & 0.76 \\
\hline Simarouba amara & $0.66 * * *$ & $0.3 *$ & $9.9 * * *$ & \\
\hline Minquartia guianensis & $0.28 *$ & $0.15 * *$ & $0.4^{*}$ & \\
\hline Lecythis ampla & $0.70 * * *$ & 0.07 & -0.7 & $1.0 * * *$ \\
\hline
\end{tabular}

*** $\mathrm{P}<0.001, * * \mathrm{P}<0.01, * \mathrm{P}<0.05$.

\section{DISGUSSION}

\section{Light levels and fluctuations in natural tree populations}

We defined light environments of natural sapling populations on the basis of visual indices, and used these values to calculate the frequency and amplitude of light fluctuations. In each population, a large majority of individuals had crown positions of 1.5, 2.0 and/or 2.5. These crown positions correspond respectively with $1.2( \pm 0.6), 1.7( \pm 0.6), 4.5( \pm 4.0) \%$ of the open sky illumination (see Clark et al. 1993). Only four out of 70 individuals had higher crown positions, and their high crown position periods lasted for 1 to $2 \mathrm{y}$ only. Together with the results from some other studies (Bongers \& Sterck 1998, Zagt 1997), these results indicate that low light levels dominate in natural sapling populations in tropical rain forests.

Most saplings were exposed to one or more light fluctuations during the $6 \mathrm{y}$ of study when the crown position index was used to estimate light availability. In each species, more than $80 \%$ of the individuals experienced at least one light change. Most light fluctuations were from high to low crown position values. This indicates that most individuals stood in increasingly dark conditions (see also Clark \& Clark 1992). Only three individuals experienced a light change from low or intermediate side light levels to direct light from above. In each case, the higher light radiation from above disappeared within $2 \mathrm{y}$. Thus, the majority of individuals was exposed to various levels of side light, and the few that had direct light from above had so for only a few years. This indicates that saplings that become more exposed after a tree or branch fall face rapidly declining light levels. Possibly, at $1 \mathrm{~m}$ in La Selva, neighbouring saplings grew up more rapidly than the saplings of our study and closed the gap relatively quickly. In contrast, at the forest level, canopy closure may take more time, e.g. 5-10 y (van der Meer 1997). 
Crown traits and light fluctuations: two hypotheses

We formulated two new hypotheses on the responses in crown traits to light fluctuations. The hypotheses are based on correlations between crown traits in 1994 and light data from 1988 to 1994. Crown traits were correlated with current and past light levels. Crown cover, the number of leaves, leaf or leaflet size, and leaf area were positively correlated. Similar correlations were found for other tropical rain forest seedlings (e.g. Augspurger 1984) and saplings (King 1994). Leaf area index tended to be negatively correlated with current and past light (or crown position) in Dipteryx and Simarouba, while there was no such trend in the other species. The negative correlation contradicts the idea that a lower leaf area index at low light is of adaptive value (leaf self-shading reduction, Horn 1971).

The first hypothesis follows from the following overall pattern: the correlations increased from low non-significant levels in 1988 to significant levels in 1991 and 1992 (Dipteryx and Simarouba) or 1993 (Lecythis) and then decreased again to lower non-significant levels in 1994. This pattern does not simply refer to the autocorrelation among light levels in successive years. In that case, we would expect the correlations between crown parameters and light levels to start at their lowest level in 1988 and to increase towards their highest level in 1994. In contrast, the correlations increased to their highest levels in the 23 y (Dipteryx and Simarouba) or 1 y (Lecythis) preceding the crown measurements. In view of this, we hypothesise that these saplings need 1-3 y to establish their major crown trait change in response to light in the forest.

In the second hypothesis we relate the response delay of the species to their architecture and development. Our saplings had longer response delays than seedlings grown in acclimation studies (e.g. Ackerly 1997, Popma \& Bongers 1991), possibly because they were older and larger, had slower inherent growth rates, and were exposed to smaller light contrasts. In our study, Lecythis seemed to respond faster than Dipteryx and Simarouba. While this is not related to size or light contrast, it might be related to the energy needed to produce new leaf area. While Dipteryx and Simarouba produce a large and thick internode and a large compound leaf, Lecythis produces a short and thin internode with a small leaf (F. J. Sterck et al., unpubl. data). This will enable the latter species to vary its leaf area on a finer scale than saplings like Dipteryx and Simarouba with an average of three to nine big leaves. We hypothesise that this ability favours a rapid response in crown traits in an environment that is dominated by relatively low light levels. The rapid responses that have been found for pioneer tree species with large internodes and large leaves were associated with large light contrasts, including open site conditions (Ackerly 1997).

\section{Ecological consequences}

How quick are growth responses relative to the temporal changes in the light environment? Levins (1968) and others (e.g. Ackerly 1997) distinguished rapid from slow responses, relative to the fluctuation rate in light levels. In a 
rapid response the trait tracks the environment, i.e. the response is established before the environment has changed. In a slow response the trait does not track the environment, but integrates short-term environmental variability. Our results indicate that individuals need $1-3$ y to establish a crown trait response and that most individuals (55-75\%) experienced maximally one major light change in $6 \mathrm{y}$. Levins' theory suggest that most individuals respond quickly enough to track the environment, in particular in the fast responding species Lecythis. Thus, in most individuals of Lecythis, Dipteryx and Simarouba the crown trait is established in the environment it is adapted to and might thus contribute optimally to further plant performance.

We did not directly relate response rate to plant performance, but studied the influence of leaf area on plant performance. Together with the light levels across the leaf area and the efficiency of converting light energy to assimilates, leaf area determines the whole plant carbon gain and is therefore important for sapling survival and growth. Although not analysed statistically, trees with smaller leaf area had lower chances of survival: the few trees that died between 1994 and 1995 (four for Dipteryx, two for Simarouba, and one for Minquartia) had the smallest leaf areas. The survivors with the larger leaf area had higher growth rates than did individuals with smaller leaf areas in Dipteryx, Simarouba and Minquartia, but not significantly in Lecythis. Thus, contrary to our prediction, there is no evidence that the crown trait affects the performance in the species with the fastest response (Lecythis), while it did in the other species. Conversely, Lecythis had no losses in 1994-1995 and its growth rate increased with light level. We do not know how this relates to its fast response time. We conclude that crown trait responses to light fluctuations influence sapling performance in natural populations but we were unable to relate this to the response rate of the species.

The present study provides a method for accessing (1) plant trait responses, (2) the time delays in these responses, and (3) the consequences of these responses for sapling performance under natural forest light conditions. Compared with the seedling experiments, response delays were hard to prove owing to gradual light fluctuations (causing autocorrelation among light levels) and the small range of light levels (with few high light levels) encountered within our samples. Yet, the study provides new information on light fluctuations under natural conditions. Moreover, on the basis of our results, two new hypotheses were formulated, one suggesting that plant responses can be much longer than those found in seedling experiments (Ackerly 1997, Popma \& Bongers 1991), and the other suggesting that time delays in plant trait responses depend on the architectural traits of the species.

\section{AGKNOWLEDGEMENTS}

We thank D. Ackerly, P. A. Jansen, D. King, P. J. van der Meer, R. Peters, L. Poorter, H. H. T. Prins, T. Rijkers, and two anonymous reviewers for their 
comments on earlier drafts of the manuscript. L. Campos and W. Brenes measured long-term growth and micro-site data. Logistic support was provided by the La Selva staff of the Organisation of Tropical Studies. Partial financial support was provided to D.A. Clark and D.B. Clark by U.S. National Science Foundation grants BSR8516371, BSR8918185, and DEB9407581, and by the Andrew W. Mellon Foundation. F.J. Sterck was supported by grant W 85-239 from the Netherlands Foundation for the Advancement of Tropical Research (WOTRO).

\section{LITERATURE GITED}

ACKERLY, D. 1997. Allocation, leaf display, and growth in fluctuating light environments. Pp. 231-264 in Bazzaz, F. A. \& Grace, J. (eds). Plant resource allocation. Academic Press, San Diego.

AUGSPURGER, C. K. 1984. Light environments of neotropical tree seedlings: a comparative study of growth and survival. Journal of Ecology 72:777-795.

BONGERS, F. \& STERCK, F. J. 1998. The architecture of tropical rain forest trees: responses to light. Pp. 126-162 in Newbery, D. M., Prins, H. H. T. \& Brown, N. D. (eds). Dynamics of tropical communities. $37^{\text {th }}$ Symposium of the British Ecological Society. Blackwell Science, Oxford.

CHAZDON, R. L. \& FETCHER, N. 1984. Light environments of tropical forests. Pp. 27-36 in Medina E., Mooney, H. A. \& Vasquez-Yanes, C. (eds). Physiological ecology of plants of the wet tropics. W. Junk, The Hague.

CHAZDON, R. L. 1988. Sunflecks and their importance to understorey plants. Advances in Ecological Research 18: 1-63.

CLARK, D. A. \& CLARK, D. B. 1987. Analysis de la régéneration de arboles del dosel en bosque muy humedo tropical: aspectos teoréticos y practicos. Revista de Biologia Tropical 35:41-54.

CLARK, D. A. \& CLARK, D. B. 1992. Life history diversity of canopy and emergent trees in a Neotropical rain forest. Ecological Monographs 62:315-44.

CLARK, D. B., CLARK, D. A. \& RICH, P. M. 1993. Comparative analysis of microhabitat utilization by saplings of nine tree species in neotropical rain forest. Biotropica 25:397-407.

CLARK, D. B., CLARK, D. A., RICH, P. M., WEISS, S. \& OBERBAUER, S. F. 1996. Landscape-evaluation of understory light and canopy structure: methods and application to a neotropical lowland rain forest. Canadian Journal of Forest Research 26:747-757.

DAWKINS, H. C. \& FIELD, D. R. B. 1978. A long-term surveillance system for British woodland vegetation. Department of Forestry, Oxford University, Oxford, England. 122 pp.

FETCHER, N., OBERBAUER, S. F. \& STRAIN, B. R. 1987. Efectos del regimen de luz sobre la fotosintesis y el crecimiento en plantulas de arboles de un bosque lluvioso tropical de Costa Rica. Revista de Biologia Tropical 35:97-110.

GROSS, L. J. 1986. Photosynthetic dynamics and plant adaptation to environmental variability. Lectures on Mathematics in the Life Sciences 19:135-170.

HARTSHORN, G. S. 1983. Plants. Pp. 118-157 in Janzen, D. H. (ed.). Costa Rican natural history. University of Chicago Press, Chicago, IL.

HORN, H. S. 1971. The adaptive geometry of trees. Princeton University Press, Princeton, NJ. 144 pp.

KING, D. A. 1994. Influence of light level on the growth and morphology of saplings in a Panamanian forest. American Journal of Botany 81:948-957.

KOHYAMA, T. 1987. Significance of architecture and allometry in saplings. Functional Ecology 1:399-404.

KOHYAMA, T. \& HOTTA, M. 1990. Significance of allometry in tropical saplings. Functional Ecology $4: 515-521$.

LEVINS, R. 1968. Evolution in changing environments: some theoretical explorations. Princeton University Press, Princeton, NJ. 120 pp.

OBERBAUER, S. F., CLARK, D. B., CLARK, D. A., RICH, P. M. \& VEGA, G. 1993. Light environment, gas exchange, and annual growth of saplings of three species of rain forest trees in Costa Rica. Journal of Tropical Ecology 9:511-524.

OSUNKOYA, O. O. \& ASH, J. E. 1991. Acclimation to a change in light regime in seedlings of six Australian rain forest tree species. Australian Journal of Botany 39:591-605.

POPMA, J. \& BONGERS, F. 1988. The effect of canopy gaps on growth and morphology of seedlings of rain forest species. Oecologia 75:625-632.

POPMA, J. \& BONGERS, F. 1991. Acclimation of seedlings of three tropical rain forest species to changing light availability. Journal of Tropical Ecology 7:85-97. 
RICH, P. M., CLARK, D. B., CLARK, D. A. \& OBERBAUER, S. F. 1993. Long-term study of solar radiation regimes in a tropical wet forest using quantum sensors and hemispherical photography. Agricultural and Forest Meteorology 65:107-127.

SANFORD, R. L., JR., PAABY, P., LUVALL, J. C. \& PHILLIPS, E. 1994. Climate, geomorphology, and aquatic systems. Pp. 19-33 in McDade, L. A., Bawa, K. S., Hespenheide, H. A. \& Hartshorn, G. S. (eds). La Selva: ecology and natural history of a neotropical rain forest. University of Chicago Press, Chicago. STERCK, F. J. 1997. Trees and light: tree development and morphology in relation to light availability in a tropical rain forest in French Guiana. PhD thesis, Wageningen Agricultural University, Ponser \& Looijen, Wageningen. 122 pp.

VAN DER MEER, P. J. 1997. Vegetation development in canopy gaps in a tropical rain forest in French Guiana. Selbyana 18:38-50.

ZAGT, R. J. 1997. Tree demography in the tropical rain forest of Guyana. PhD Thesis. Tropenbos-Guyana Series 3. Utrecht. $251 \mathrm{pp}$ 